\title{
Incidence of endophthalmitis after cataract surgery (2002-2008) at a Brazilian university-hospital
}

\author{
Incidência de endoftalmite após cirurgia de catarata (2002-2008) \\ num hospital universitário brasileiro
}

Gustavo Barreto Meloํㅡ. Paulo José Martins Bispo², Caio Vinícius Saito Regatieri ${ }^{1}$, Maria Cecília Zorat Yu ${ }^{3}$, Antônio Carlos Campos Pignatari ${ }^{4}$, ANA LUISA HöFLING-LIMA ${ }^{1}$

\section{ABSTRACT}

Purpose: To report on the incidence, diagnostic technique, and microbiological features of endophthalmitis at a university-setting in Brazil.

Methods: All cases of presumed postoperative endophthalmitis from 2002 to 2008 at a teaching-hospital were included. Main data assessed were: number of cataract surgeries performed, incidence of endophthalmitis, microbiological outcome (aqueous and/or vitreous culture and Gram staining), and antimicrobial susceptibility testing of the positive cases.

Results: Seventy-three eyes of 73 patients (43 females and 30 males) developed endophthalmitis after 24,590 cataract surgeries. The incidence decreased from $0.49 \%$ in 2003 to $0.17 \%$ in 2006 and stabilized afterwards. Coagulase negative Staphylococci (CoNS) and Streptococcus viridans (56.5\% and 15\%, respectively) were the most common bacterial isolates. Culture and Gram stain were negative in $36.9 \%$. CoNS presented susceptibility rates of $80 \%$ sensitivity to oxacillin, $90 \%$ to fourth-generation quinolones and $100 \%$ to vancomycin.

Conclusions: The rate of endophthalmitis, diagnostic ability of conventional laboratory investigation, microbial isolates and antibiotic susceptibility are in accordance with other findings of the literature. Despite using prophylactic antibiotic drops, it was possible to identify cases that were susceptible to the antibiotics topically applied.

Keywords: Endophthalmitis/epidemiology; Endophthalmitis/etiology; Endophthalmitis/diagnosis; Endophthalmitis/microbiology; Cataract extraction/adverse effects

\section{RESUMO}

Objetivo: Relatar incidência, técnica diagnóstica e características microbiológicas de endoftalmite numa instituição universitária no Brasil.

Métodos: Todos os casos de endoftalmite pós-operatória presumida de 2002 a 2008 foram incluídos. Os principais dados avaliados foram: número de cirurgias de catarata realizadas, incidência de endoftalmite, resultado microbiológico (bacterioscopia e cultura de aquoso e vítreo) e teste de sensibilidade antibiótica dos casos positivos.

Resultados: Setenta e três olhos de 73 pacientes (43 do sexo feminino e 30 do masculino) desenvolveram endoftalmite após 24.590 cirurgias de catarata. A incidência reduziu de 0,49\% em 2003 para 0,17\% em 2006 e estabilizou-se depois disso. Staphylococcus coagulase-negativa (SCON) e Streptococcus viridans (56.5\% e 15\%, respectivamente) foram os isolados bacterianos mais comuns. Cultura e bacterioscopia foram negativas em 36,9\%. SCoN apresentou taxas de sensibilidade de $80 \%$ à oxacilina, $90 \%$ às quinolonas de quarta geração e $100 \%$ à vancomicina.

Conclusões: A taxa de endoftalmite, a capacidade diagnóstica das técnicas laboratoriais convencionais, os microrganismos isolados e a sensibilidade aos antibióticos estão em acordo com outros achados na literatura. Apesar do uso profilático de colírio antibiótico, foi possível identificar casos de infecção em que as bactérias eram sensiveis aos antibióticos usados topicamente.

Descritores: Endoftalmite/epidemiologia; Endoftamite/etiologia; Endoftalmite/diagnóstico; Endoftalmite/microbiologia; Extração de catarata/efeitos adversos

\section{INTRODUCTION}

nfectious endophthalmitis following cataract surgery still is a devastating condition, despite major improvements in surgical techniques in the last decades. Most series report on an

Study carried out at the Federal University of São Paulo - UNIFESP - São Paulo (SP), Brazil. ${ }^{1}$ Physician, Department of Ophthalmology, Universidade Federal de São Paulo - UNIFESP São Paulo (SP), Brazil.

Biomedical, Special Laboratory of Clinical Microbiology, Department of Medicine, Universidade Federal de São Paulo - UNIFESP - São Paulo (SP), Brazil.

Biomedical, Ocular Microbiology Laboratory, Universidade Federal de São Paulo - UNIFESP - São Paulo (SP), Brazil.

${ }^{4}$ Physician, Special Laboratory of Clinical Microbiology, Department of Medicine, Universidade Federal de São Paulo - UNIFESP - São Paulo (SP), Brazil.

Correspondence address: Gustavo Barreto de Melo. Rua Botucatu, 822 - São Paulo (SP) - CEP 04023-062 - Email: gustavobmelo@oftalmo.epm.br

Recebido para publicação em 20.06.2010

Última versão recebida em 08.11.2010

Aprovação em 15.11.2010

Esse estudo teve apoio da FAPESP e da CAPES

Nota Editorial: Depois de concluída a análise do artigo sob sigilo editorial e com a anuência do Dr. José Beniz Neto sobre a divulgação de seu nome como revisor, agradecemos sua participação neste processo. incidence rate ranging from $0.05 \%$ to $0.4 \%$ in different studies worldwide ${ }^{(1)}$.

Most cases are caused by Gram-positive microorganisms present in the conjunctiva and the eyelid. Prophylactic procedures include the use of preoperative and postoperative antibiotics and preoperative povidone. Its management requires a prompt intervention, such as a vitreous tap followed by intravitreal injection of antibiotics or vitrectomy ${ }^{(2)}$.

Herein, we present the rates of endophthalmitis at a university setting in Brazil, where surgeries are predominantly performed by residents and fellows. Additionally, we compare these rates prior and after the introduction of fourth-generation quinolones as postoperative prophylactic drops.

\section{METHODS}

This was a retrospective study based on the medical records of the Departments of Ophthalmology and Ocular Microbiology Laboratory (LOFT) at the Federal University of São Paulo, Brazil.

Data from patients who had been previously submitted to cataract surgery (alone or combined with trabeculectomy) 
were examined and presented with presumed infectious endophthalmitis from 2002 to 2008.

The following data were assessed: number of cataract surgeries performed per year and number of endophthalmitis cases, gender, age, interval from surgery to diagnosis, prophylactic use of antibiotics eye drops, microbiological outcome (aqueous and/or vitreous culture and Gram staining), and antimicrobial susceptibility testing of the positive cases.

The incidence of endophthalmitis was established per year and for the whole period of the study based on its clinical diagnosis. It should be stated that all patients were operated on and followed at the same institution. Patients operated on elsewhere were excluded from this analysis. Antibiotic drops were administered 30 minutes before surgery and for 7 days afterwards (q.i.d.).

The patients were submitted to either vitreous/aqueous tap or vitrectomy followed by intravitreal injection of antibiotics. Intraocular specimens were collected and cultured on blood agar, chocolate agar, fastidious anaerobic thioglycolate broth, and Sabouraud agar for aerobic and anaerobic bacteria, and fungi. Gram stain and acid-fast stain were performed immediately. A positive culture was defined as either separate colonies of the same organism on two or more separate culture plates or confluent growth at the site of inoculation. Antimicrobial susceptibility testing was performed by the disc diffusion method. Current version of CLSI document M-100, published annually, was used for zone diameter interpretation.

\section{RESULTS}

Seventy-three eyes of 73 patients (43 females and 30 males) developed presumed postoperative endophthalmitis after cataract surgery alone (71 cases) or combined with trabeculectomy (2 cases) from 2002 to 2008 at our institution. Demographic data are disclosed in table 1. Most patients were elderly and were under antibiotic drops after surgery until the development of the infection. Mean time interval from surgery to clinical diagnosis was 8.5 days.

In the period of time of this study (2002-2008), 24,590 cataract surgeries were performed at our setting, keeping a regular distribution yearly. Incidence of presumed endophthalmitis varied from a peak of $0.49 \%$ in 2003 to a trough of $0.17 \%$ in 2006 . The rate of endophthalmitis decreased by half when the last 3 years were compared to the 2 initial years. Detailed data are presented in table 2. Overall incidence of endophthalmitis was $0.29 \%$. Microbiological techniques were able to confirm $63 \%$ of the clinically suspected cases.

Bacterial species identified are disclosed in table 3. Coagulase negative Staphylococci (CoNS) were responsible for 56.5\% of all positive cases from 2002 to 2008; Streptococcus viridans was positive in 15\% of the identified cases; Proteus mirabilis, Pseudomonas aeruginosa and Staphylococcus aureus corresponded each to $4 \%$ of these cases; other microorganisms were identified in one case each. Among all 73 presumed cases of endophthalmitis, 27 (36.9\%) were negative either in culture or in Gram staining.

Antimicrobial susceptibility testing was performed for every positive case of infectious endophthalmitis. None of the Gram-positive isolates were resistant to vancomycin. Five samples of CoNS, and 2 of Staphylococcus aureus were resistant to oxacillin. Among these, one sample of CoNS was also resistant to gatifloxacin and another one to moxifloxacin. These patients were under prophylactic drops of moxifloxacin postoperatively. No other sample of bacteria isolated from these endophthalmitis cases was resistant to the fourth-generation quinolones. It is important to state that during the period of time
Table 1. Demographic data from the cases $(n=73)$

\begin{tabular}{lcc}
\hline Age (mean \pm SD) & Male & $67.6 \pm 11.4$ \\
Gender & Female & 30 \\
& & 43 \\
Interval (days) between surgery & & $8.5 \pm 10.11$ \\
and diagnosis (mean \pm SD) & Yes & 57 \\
Prophylactic postoperative & No & 1 \\
use of antibiotic drops & Not available & 15 \\
&
\end{tabular}

assessed in this study, antibiotic susceptibility with fourth-generation quinolones was applied to 10 positive samples. Therefore, there was an $80 \%$-sensitivity to this class of antibiotic (90\% to gatifloxacin and 90\% moxifloxacin each).

\section{DISCUSSION}

The incidence of endophthalmitis following cataract surgery has varied over the last decades as described in the literature. In the 1970s, it was $0.32 \% ; 0.16 \%$ in the 1980s; $0.08 \%$ in the 1990s; and showed a trend to increase in the early years of the 21 st century, reaching $0.26 \%{ }^{(1)}$. The increased rate of endophthalmitis after cataract extraction has been temporally associated with the use of sutureless clear cornea incisions. This may be caused by wound defect (including wound leakage), early postoperative hypotony (leading to the inflow of the eyelid microorganisms) and possibly the lack of the conjunctiva covering the corneal incision. The overall rate of endophthalmitis at our setting from 2002-2008 (0.29\%) was very similar to the one reported on this systematic review of the literature.

Interestingly, this rate significantly decreased by half from 2002 and 2003 to the following years. Within this period, there was no significant difference in surgical techniques in worldwide phacoemulsification that could explain these data. We hypothesize two possible explanations. First, the phacoemulsification teaching method changed at our institution. Previously, residents that had never done a phacoemulsification would simply begin operating on patients with the assistance from the first to the last step. Later on and nowadays, the residents have to do their first surgeries by performing the last steps, such as corneal suturing and IOL implantation. Only after acquiring some experience, they can perform initial steps and the whole surgery. It is believed that this method might have decreased the rate of surgical complications. However, the impact of the new teaching methodology has not been assessed into details and there are no published data from our service to clearly support this theory. Another possible explanation to a decreased incidence in the latest years is the use of fourth-generation quinolones. They have been routinely used as a postoperative prophylaxis since 2004/2005. And besides, they have been donated to the patients for the postoperative period. Although this association is hardly proven, another study showed a marked reduction in endophthalmitis incidence with fourth-generation quinolones in comparison to the third-generation ones ${ }^{(3)}$.

One might expect our incidence would be higher than the average since the majority of the cataract surgeries are performed either by residents or fellows. It is well known that surgical complications, such as posterior capsule disruption with vitreous loss, are significant risk factors for the development of this infection. It is also expected that surgeons-intraining be responsible for more cases developing complication $^{(4)}$. However, a small case series did not show an increa- 
Table 2. Number of performed cataract surgeries, presumed endophthalmitis cases, culture-proven cases and incidence of endophthalmitis per year and overall rates

\begin{tabular}{|c|c|c|c|c|}
\hline Year & Number of surgeries & Presumed endophthalmitis & Culture-proven cases & Incidence (\%) \\
\hline 2002 & 3876 & 18 & 11 & 0.46 \\
\hline 2003 & 3663 & 18 & 13 & 0.49 \\
\hline 2004 & 3596 & 10 & 5 & 0.28 \\
\hline 2005 & 3248 & 8 & 5 & 0.24 \\
\hline 2006 & 3572 & 6 & 4 & 0.17 \\
\hline 2007 & 3164 & 6 & 4 & 0.19 \\
\hline 2008 & 3471 & 7 & 4 & 0.20 \\
\hline Overall & 24590 & 73 & 46 & 0.29 \\
\hline
\end{tabular}

Table 3. Microbiological characterization for the whole period of the study (2002-2008). Percentage refers only to the positive cases

\begin{tabular}{lcc}
\hline Bacterial species & $\mathbf{n}$ & \% \\
\hline Coagulase negative Staphylococci & 26 & 56.5 \\
Streptococcus viridans & 7 & 15.2 \\
Proteus mirabilis & 2 & 4.3 \\
Pseudomonas aeruginosa & 2 & 4.3 \\
Staphylococcus aureus & 2 & 4.3 \\
Streptococcus pneumoniae & 1 & 2.1 \\
B-hemolytic Streptococcus (group G) & 1 & 2.1 \\
Morganella morganii & 1 & 2.1 \\
Enterococcus spp & 1 & 2.1 \\
Haemophilus spp & 1 & 2.1 \\
Acinetobacter & 1 & 2.1 \\
Weeksella virosa & 1 & 2.1 \\
Positive Gram staining/negative culture & 1 & 2.1 \\
Negative culture/Gram staining & 27 & NA \\
Total positive cases & 46 & 100 \\
Total & 73 & $\mathrm{NA}$ \\
\hline
\end{tabular}

NA= not applicable

sed incidence of endophthalmitis after cataract surgery performed by residents ${ }^{(5)}$. We believe that our results, although presenting an average rate of infection according to the systematic review of literature, is probably higher than it could be due to the higher rate of surgical complications found in surgeries performed by surgeons-in-training.

Laboratory investigation was able to diagnose $63 \%$ of the presumed infectious endophthalmitis cases. This is in accordance with most studies, in which culture sensitivity varies from 30 to $80 \%{ }^{(6-7)}$. The sensitivity is increasingly higher with vitreous tap and vitrectomy in comparison to aqueous tap ${ }^{(6)}$.

CoNS are the most common causative microorganisms of infectious endophthalmitis in most series, usually followed by Streptococci(8-9). This was exactly what we found in our study. In the Endophthalmitis Vitrectomy Study, for example, 70\% of the causative microorganisms were CoNS and about 9\% were Streptococci and Staphylococcus aureus each ${ }^{(8)}$. A previous study published by our group also showed a similar distribution of microorganisms regarding all cases of endophthalmitis, including the endogenous and traumatic ones ${ }^{(9)}$.

Despite the lack of clear evidence favoring the use of prophylactic postoperative antibiotics, they are commonly used in most clinical settings. However, this may trigger antibiotic resistance. In two previous studies, it was shown that $68 \%$ of
CoNS were sensitive to third generation quinolones ${ }^{(10-11)}$. We showed a 92\%-susceptibility to ciprofloxacin in our previous report ${ }^{(9)}$. In our current series, we found an $80 \%$-susceptibility of CoNS to oxacillin, and a 90\%-sensitivity to gatifloxacin or moxifloxacin.

In summary, this study provides information on a large series of endophthalmitis in a single-center from 2002 to 2008. Overall incidence was $0.29 \%$ and showed a marked decrease from 2004 on; laboratory investigation was able to diagnose $63 \%$ of the presumed infectious cases; CoNS were the most common microorganisms; and there still is a high rate of antibiotic susceptibility in our institution. These data are consistent with other studies in worldwide literature. One of the main points raised by this report and whose answer remains unknown is how prophylactic antibiotic drops can influence the rate of infectious endophthalmitis. Other important issue is the low sensitivity of the conventional laboratory diagnostic techniques. The clinical application of molecular diagnostic tools should be taken into account. These topics should be addressed in future studies.

\section{REFERENCES}

1. Taban M, Behrens A, Newcomb RL, Nobe MY, Saedi G, Sweet PM, McDonnell PJ. Acute endophthalmitis following cataract surgery: a systematic review of the literature. Arch Ophthalmol. 2005;123(5):613-20

2. Kim JY, Ali R, Cremers SL, Henderson BA. Perioperative prophylaxis for postcataract extraction endophthalmitis. Int Ophthalmol Clin. 2007:47(2):1-14

3. Jensen MK, Fiscella RG, Moshirfar M, Mooney B. Third- and fourth-generation fluoroquinolones: retrospective comparison of endophthalmitis after cataract surgery performed over 10 years. J Cataract Refract Surg. 2008;34(9):1460-7. Comment in: J Cataract Refract Surg. 2009;35(2):206; author reply 207-9. J Cataract Refract Surg. 2009:35(2):206-7; author reply 207-9.

4. Blomquist PH, Rugwani RM. Visual outcomes after vitreous loss during cataract surgery performed by residents. J Cataract Refract Surg. 2002;28(5):847-52.

5. Hollander DA, Vagefi MR, Seiff SR, Stewart JM. Bacterial endophthalmitis after resident-performed cataract surgery. Am J Ophthalmol. 2006;141(5):949-51.

6. Donahue SP, Kowalski RP, Jewart BH, Friberg TR. Vitreous cultures in suspected endophthalmitis. Biopsy or vitrectomy? Ophthalmology. 1993:100(4):452-5.

7. Goldschmidt P, Degorge S, Benallaoua D, Basli E, Batellier L, Boutboul S, et al. New test for the diagnosis of bacterial endophthalmitis. Br J Ophthalmol. 2009;93(8): 1089-95.

8. Han DP, Wisniewski SR, Wilson LA, Barza M, Vine AK, Doft BH, Kelsey SF. Spectrum and susceptibilities of microbiologic isolates in the Endophthalmitis Vitrectomy Study. Am J Ophthalmol. 1996;122(1):1-17. Erratum in: Am J Ophthalmol. 1996 Dec;122(6): 920

9. Bispo PJM, Melo GB, d'Azevedo PA, Höfling-Lima AL, Yu MCZ, Pignatari ACC. Culture proven bacterial endophthalmitis: a 6-year review. Arq Bras Oftalmol. 2008; 71(5):617-22.

10. Benz MS, Scott IU, Flynn HW Jr, Unonius N Miller D. Endophthalmitis isolates and antibiotic sensitivities: a 6-year review of culture-proven cases. Am J Ophthalmol. 2004;137(1):38-42. Comment in: Am J Ophthalmol. 2004;137(6):1167-8; author reply 1168. Am J Ophthalmol. 2004;137(6):1169; author reply 1169-70.

11. Eser I, Kapran Z, Altan T, Ozel Karatas M, Aydin D, Okaygun E, Yilmaz OF. Isolates and antibiotic sensitivity of eighty culture-proven endophthalmitis cases from Istanbul. Ophthalmologica. 2008;222(3):157-60. 